Keio J. Med. 32: 73-80, 1983

\title{
APPEARANCE OF REVERSE TRANSCRIPTASE ACTIVITY IN HUMAN FETAL THYMUS CELLS STIMULATED BY HUMAN B-CELL*1
}

\author{
AKIRA ONO ${ }^{* 2}$, HIDETSUGU SAITO*3, TORU HIGASHINAKAGAWA*4, \\ TATSUYA NAKAMURA*3, SHUNZO KONDO ${ }^{* 5}$, \\ HIROSHI YOSHIMATSU ${ }^{* 6}$ and MASAHARU TSUCHIYA $* 3$ \\ *2 Department of Virology, The Kitasato Institute, 5-9-1 Shirokane, \\ Minato-ku, Tokyo 108 \\ *3 Department of Internal Medicine, School of Medicine, Keio University, \\ 35 Shinanomachi, Shinjuku-ku, Tokyo 160 \\ *4 Department of Biology, Tokyo Metropolitan University, 2-1-1 Fukazawa, \\ Setagaya-ku, Tokyo 158 \\ *5 Department of Developmental Biology, Misubishi-Kasei Institute of \\ Life Science, 11 Minamiooya, Machida-shi, Tokyo 194 \\ ${ }^{*}$ Department of Surgery, University of Occupational and Environmental \\ Health, 1-1 Iseigaoka, Yahatanishi-ku, Kitakyushu 807, Japan
}

(Received for publication June 15, 1983)

\begin{abstract}
We have investigated three human fetal thymuses by various induction procedures in a search for retrovirus. Thymus cells were cultured for 7 days together with mitomycin C-treated B cells and examined for reverse transcriptase activity. The following results were obtained. 1) RNA-directed DNA polymerase (RDDP) activity was detected in the culture medium on day 3 and persisted until day 7. This enzyme, after partial purification on phosphocellulose column, showed template-primer specificity of a typical reverse transcriptase. 2) In unstimulated thymus cells, no reverse transcriptase activity was detected. 3) Stimulation with lymphocyte mitogens such as phytohaemagglutinin (PHA) and concanavalin A (Con A) exerted no effect on inducing the reverse transcriptase activity. 4) No reverse transcriptase activity was obtained in the culture medium of B cells pretreated with mitomycin C. Taken together these results indicate that in human fetal thymus cells reverse transcriptase activity is induced by human $B$ cell stimulation, pointing to an intriguing possibility of protovirus activation.
\end{abstract}

*1 Supported in part by grants from the Ministry of Education, Science and Culture, the Ministry of Health and Welfare, and the Ministry of Labor, Japan. 
RNA tumor viruses (retroviruses) have been shown to be involved in the pathogenesis of leukemias, lymphomas, sarcomas and so forth in several species of animals. ${ }^{1-3}$ Most of retroviruses are considered to be endogenous, since they are induced in normal cells and since molecular hybridization studies have shown that their proviruses are integrated into the cell genome. ${ }^{4-6}$ In humans, several authors have detected retroviruses in cells of malignant tumors such as leukemias $^{7-10}$ and also in normal tissues such as placentas. ${ }^{11,12}$ However, an inducible, endogenous retrovirus has not yet been demonstrated in humans.

In order to determine whether the findings in animals could be applied to humans, we searched for endogenous retrovirus in human thymus cells by various induction procedures. The reasons why thymus cells were chosen were: 1) The thymus is considered to be the primary site of neoplastic transformation in spontaneous leukemia in AKR mice. ${ }^{13}$ 2) The existence of Tla (thymus-leukemia antigen) on murine thymus cells. ${ }^{1+} 3$ ) Retroviruses have been detected in human adult $\mathrm{T}$-cell leukemias ${ }^{15,16}$ and the thymus is considered to be a central lymphoid tissue. ${ }^{17}$

In this paper, we present evidence for the appearance of reverse transcriptase activity in human fetal thymus cells. As judged by template-primer specificity and chromatographic behavior on phosphocellulose column, the enzyme was shown to be an RNA-directed DNA polymerase (RDDP) and such reverse transcriptase activity is seen in human fetal thymus cells only when they are stimulated by human $B$ cells. The results suggest the intriguing possibility that RNA tumor protovirus can be activated in normal human thymus cells.

\section{MATERIALS AND METHODS}

\section{Cells and Cell Culture Methods}

Three human fetal thymuses were obtained by abortion (from 14 to 20 weeks old) and thymus cell suspensions were prepared as described.18,19 These suspensions consisted of 70-90\% thymic lymphocytes and 10-30\% non-lymphoid cells including thymus epithelial cells. Two B cell lines, CCRF-SB, ${ }^{20}$ Raji, ${ }^{21}$ were used as stimulator cells. The thymus cells $\left(5 \times 10^{6}\right.$ cells/well $)$ were cultured for 7 days at $37^{\circ} \mathrm{C}$ in an atmosphere of $5 \% \quad \mathrm{CO}_{2} / 95 \%$ air together with $\mathrm{B}$ cells $\left(1 \times 10^{\circ}\right.$ cells/well) pretreated with mitomycin C (Kyowa, $25 \mu \mathrm{g} / \mathrm{ml}, 37^{\circ} \mathrm{C}, 30 \mathrm{~min}$ ). On day 4 , a second stimulation by $\mathrm{B}$ cells was applied. On day 1, 3, 5 and 7 the culture medium was collected and processed for the assay of RNA-directed DNA polymerase (RDDP) activity. The following induction procedures were also applied to fetal thymus cells, culturing with either phytohaemagglutinin-P $(1 \mu \mathrm{g} / \mathrm{ml})$, concanavalin A $(10 \mu \mathrm{g} / \mathrm{ml})$, lipopolysaccharide $(10 \mu \mathrm{g} / \mathrm{ml})$ or pokeweed mitogen $(10 \mu \mathrm{g} / \mathrm{ml})$, and pretreatment with bromodeoxyuridine (BUDR, 
$50 \mu \mathrm{g} / \mathrm{ml}$, Difco) or mitomycin C. The culture medium was collected on day 3 and examined for RDDP activity. In order to exclude the possibility that the stimulator $B$ cells were contaminated with retroviruses, both fresh and mitomycin $\mathrm{C}$ treated $\mathrm{B}$ cells were checked for RDDP activity. B cells pretreated with BUDR $(100 \mu \mathrm{g} / \mathrm{ml})$ were also studied in the same way. As a control of RDDP activity, murine leukemia virus (MuLV) producer cell lines were used.22

Partial Purification of the RDDP Activity

The culture medium was collected and centrifuged at $2,000 \times \mathrm{g}$ to remove cell debris. The supernatant was centrifuged at $105,000 \times \mathrm{g}$ for $90 \mathrm{~min}$ at $4^{\circ} \mathrm{C}$ and the pellet was resuspended in buffer $\mathrm{A}(0.05 \mathrm{M}$ Tris- $\mathrm{HCl}, \mathrm{pH} 7.5,50 \mathrm{mM}$ $\mathrm{KCl}, 5 \mathrm{mM} \mathrm{MgCl}, 5 \mathrm{mM}$ dithiothreitol). An aliquot of this suspension was placed onto the top of $20-60 \% \mathrm{w} / \mathrm{v}$ sucrose gradients in buffer $\mathrm{A}$ and centrifuged for $18 \mathrm{hrs}$ at $150,000 \times \mathrm{g}$ at $4^{\circ} \mathrm{C} .23$ Fractions $(0.25 \mathrm{ml})$ were collected from the bottom and assayed for RDDP activity. The density of each fraction was determined by measuring the refractive index. Sucrose density gradient fractions containing RDDP activity were pooled and mixed with an equal volume of disruption buffer (0.05 M Tris- $\mathrm{HCl}, \mathrm{pH} 7.5,1.0 \mathrm{M} \mathrm{KCl}, 1.0 \%$ Triton X, $5 \mathrm{mM}$ dithiothreitol, $20 \%$ glycerol). The pooled fractions were briefly sonicated, stirred at $4^{\circ} \mathrm{C}$ for $3 \mathrm{hrs}$ and centrifuged at $100,000 \times \mathrm{g}$ for $1 \mathrm{hr}$. The supernatant fluid was dialyzed against buffer $\mathrm{B}(0.05 \mathrm{M}$ Tris- $\mathrm{HCl}, \mathrm{pH} 7.5,5 \mathrm{mM}$ dithiothreitol, $20 \%$ glycerol) containing $0.05 \mathrm{M} \mathrm{KCl}$. The dialyzate was then chromatographed on a DEAE column $(8 \times 1.4 \mathrm{~cm}$, Whatman, DE 52) equilibrated with buffer B containing $0.05 \mathrm{M} \mathrm{KCl} .^{24}$ The column was developed with a $60 \mathrm{ml}$ linear $0.05 \mathrm{M}-0.5 \mathrm{M} \mathrm{KCl}$ gradient in buffer B. Fraction $(3 \mathrm{ml})$ were collected and assayed for DNA polymerase activity. Fractions containing enzyme activity were pooled and dialyzed against buffer $\mathrm{B}$ containing $0.05 \mathrm{M} \mathrm{KCl}$. The dialyzed solution was then applied to a phosphocellulose column $(8 \times 1.4 \mathrm{~cm}$, Whatman $\mathrm{P} 11)$ equilibrated with buffer $\mathrm{B}$ containing $0.05 \mathrm{M} \mathrm{KCl}$. The column was developed with a $60 \mathrm{ml}$ of linear $0.05-0.6 \mathrm{M} \mathrm{KCl}$ gradient in buffer B. Fractions $(3 \mathrm{ml})$ were collected and assayed for DNA polymerase activity. As a control, post-mitochondrial supernatant prepared from fresh thymus or B cells or MuLV producer cells was sonicated and stirred in the same manner. After dialysis the solution was chromatographed on a phosphocellulose column, and assayed for DNA polymerase activity.

Assays for RDDP and other DNA Polymerase Activities ${ }^{23,25}$

RDDP assays were carried out at $37^{\circ} \mathrm{C}$ for $30 \mathrm{~min}$ in a standard reaction mixture which contained in a final volume of $100 \mu \mathrm{l}: 50 \mathrm{mM}$ Tris- $\mathrm{HCl}(\mathrm{pH} 7.8)$, $60 \mathrm{mM} \mathrm{KCl}, 1 \mathrm{mM} \mathrm{MnCl}_{2}, 5 \mathrm{mM}$ dithiothreitol, $0.1 \%(\mathrm{v} / \mathrm{v})$ Triton X-100, $4 \mu \mathrm{M}$ 
${ }^{3} \mathrm{H} 1 \mathrm{dTTP} \quad(30 \mathrm{Ci} / \mathrm{mM}, 60,000 \mathrm{cpm} / \mathrm{pmole}), 2 \mu \mathrm{g}(\mathrm{rA})_{\mathrm{n}} \cdot(\mathrm{dT})_{12-18}$ and a $50 \mu \mathrm{l}$ alioquot of each fraction. When $(\mathrm{rCm})_{n} \cdot(\mathrm{dG})_{12-1 \mathrm{~s}}$ was used as the templateprimer, $4 \mu \mathrm{g}$ of $\mathrm{H}$-dGTP $(20 \mathrm{Ci} / \mathrm{mM}, 45,000 \mathrm{cpm} / \mathrm{pmole})$ was used. At the end of the reaction, $90 \mu \mathrm{l}$ samples were applied to glass fibre dises (Whatman, GF/C), which were washed 5 times in $5 \%$ TCA $/ 1 \% \mathrm{Na}_{4} \mathrm{P}_{2} \mathrm{O}_{7}$ and twice in ethanol, dried and counted in a Liquid Scintillation Spectrometer using a toluene-base scintillation fluid. DNA-directed DNA polymerase and terminal deoxynucleotidyl transferase activities were assayed using $2 \mu \mathrm{g}$ of $(\mathrm{dA})_{\mathrm{n}} \cdot(\mathrm{dT})_{12-18}$ and $2 \mu \mathrm{g}$ of $(\mathrm{dA})_{12-18}$ as the template-primer, respectively.

\section{RESULTS}

Phosphocellulose Column Chromatography of RDDP Activity

The particulate fraction obtained by centrifuging the culture medium was resuspended and applied to sucrose density gradients. A sharp peak of RDDP activity was observed at a density of $1.15-1.17 \mathrm{~g} / \mathrm{cm}^{3}$ which corresponds to that of retrovirus particles. ${ }^{23}$ This RDDP activity was detected on day 3 and persisted

Fig. 1 Phosphocellulose column chromatography of RNA-directed DNA polymerase activity. ${ }^{3} \mathrm{H}$-dTTP used as the labelled substrate for $(r A)_{n}$.

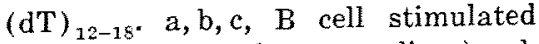
thymus cell (culture medium). d, MuLV producer cells. e, fresh thymus cells. f, B cell (Raji). g, PHAstimulated thymus cells. h, mitomycin $C$ treated $B$ cells (culture medium).

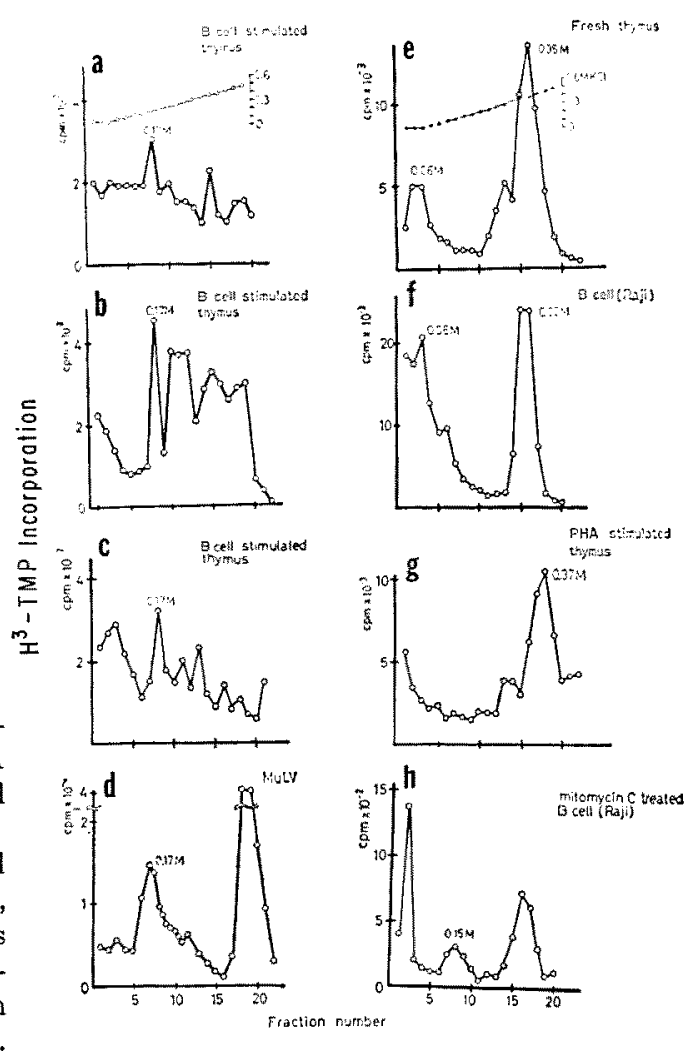


until day 7. Sucrose density gradient fractions containing RDDP activity were pooled and subjected to chromatography on phosphocellulose. Extracts of thymus cells and B cells were used as controls. The culture media of MuLV (murine leukemia virus) producer cell line, PHA-stimulated thymus cells, and mitomycin C-pretreated B cells were also examined. RDDP activity in the culture medium from MuLV producer cell lines was eluted at $0.17 \mathrm{M} \mathrm{KCl}$ (Fig. 1-d).${ }^{26}$ RDDP activity in the culture medium of $B$ cell stimulated thymus cells was also eluted at $0.17 \mathrm{M} \mathrm{KCl}$ (Fig. 1-a, b, c). Essentially, no RDDP activity was eluted at 0.17 $\mathrm{M} \mathrm{KCl}$ when the other samples were chromatographed; the RDDP activity in

Table 1

Template-primer requirement of RNA-directed DNA polymerase

The template-primer specificity of RDDP activity in B cell stimulated thymus cells was examined. Assays were carried out for $30 \mathrm{~min}$ in the reaction mixture described in Materials and Methods. The templa-prime concentration was $20 \mu \mathrm{g}$. ${ }^{3} \mathrm{H}$-dTTP was used as the labelled substrate for $(\mathrm{rA})_{n} \cdot(\mathrm{dT})_{12-1 \mathrm{~s}}$ and $(\mathrm{dA})_{\mathrm{n}}$. $(\mathrm{dT})_{12-18}$, and ${ }^{3} \mathrm{H}-\mathrm{dGTP}$ for $(\mathrm{rCm})_{\mathbf{n}} \cdot(\mathrm{dG})_{12-18}$ and $(\mathrm{dA})_{12-1 \mathrm{~s}}$. Numbers in parentheses represent the activity in the presence of $\mathrm{Mg}^{++}(10 \mathrm{mM})$ instead of $\mathrm{Mn}^{++}$ $(1 \mathrm{mM})$ as divalent cation.

\begin{tabular}{|c|c|c|c|c|}
\hline \multirow{2}{*}{ Source of protein } & \multicolumn{4}{|c|}{${ }^{3} \mathrm{H}-\mathrm{dTMP}$ or ${ }^{3} \mathrm{H}-\mathrm{dGTP}$ incorporation (cpm) } \\
\hline & $(\mathrm{rA})_{n}(\mathrm{dT})_{2-18}$ & $(\mathrm{dA})_{\mathrm{n}}(\mathrm{dT})_{12-18}$ & $(\mathrm{rCm})_{\mathrm{n}}(\mathrm{dG})_{12-18}$ & $(\mathrm{dA})_{12-18}$ \\
\hline \multicolumn{5}{|l|}{$\begin{array}{l}\text { B cell stimulated thymus } \\
\text { cella }^{a}\end{array}$} \\
\hline $\begin{array}{l}0.17 \mathrm{M} \mathrm{KC1} \text { phosphocellu- } \\
\text { lose eluate }\end{array}$ & $\begin{array}{c}499 \\
(186)\end{array}$ & 33 & $\begin{array}{l}3780 \\
(563)\end{array}$ & 0 \\
\hline \multicolumn{5}{|l|}{ Fresh thymus cell extract } \\
\hline $\begin{array}{l}0.06 \mathrm{M} \mathrm{KC1} \mathrm{phosphocellu-} \\
\text { lose eluate }\end{array}$ & 12598 & 13450 & 494 & 558 \\
\hline $\begin{array}{l}0.38 \mathrm{M} \mathrm{KC1} \text { phosphocellu- } \\
\text { lose eluate }\end{array}$ & 18860 & 15530 & 0 & 98 \\
\hline \multicolumn{5}{|l|}{ Fresh B cell (Raji) extract } \\
\hline $\begin{array}{l}0.06 \mathrm{M} \mathrm{KC1} \text { phosphocellu- } \\
\text { lose eluate }\end{array}$ & 21758 & 25528 & 0 & N.D.b \\
\hline $\begin{array}{l}0.35 \mathrm{M} \mathrm{KCl} \text { phosphocellu- } \\
\text { lose eluate }\end{array}$ & 24208 & 13672 & 0 & N.D. \\
\hline \multicolumn{5}{|l|}{$\begin{array}{l}\text { Mitomycin C-pretrated B cell } \\
\left(\text { Raji) }{ }^{\mathrm{a}}\right.\end{array}$} \\
\hline $\begin{array}{l}0.06 \mathrm{M} \mathrm{KC1} \text { phosphocellu- } \\
\text { lose eluate }\end{array}$ & 544 & 2202 & 0 & N.D. \\
\hline $\begin{array}{l}0.15 \mathrm{M} \mathrm{KC} 1 \text { phosphocellu- } \\
\text { lose eluate }\end{array}$ & 280 & 7220 & 0 & N.D. \\
\hline $\begin{array}{l}0.37 \mathrm{M} \mathrm{KC1} \mathrm{phosphocellu-} \\
\text { lose eluate }\end{array}$ & 850 & 604 & 0 & N.D. \\
\hline
\end{tabular}

a culture medium, b N.D.; not done 
extracts from fresh thymus cells, B cells and PHA-stimulated thymus cells was not eluted at $0.17 \mathrm{M} \mathrm{KCl}$, but at $0.06 \mathrm{M}$ and $0.35 \mathrm{M} \mathrm{KCl}$ (Fig. 1-e, f, g). RDDP activity in the culture medium from mitomycin C-treated $\mathrm{B}$ cells was eluted at $0.15 \mathrm{M} \mathrm{KCl}$, which is close to $0.17 \mathrm{M}$ (Fig. 1-h). However, this was accompanied by a very high activity of DNA-directed DNA polymerase and probably represented $\mathrm{EB}$ virus-associated DNA polymerase ${ }^{27}$ (see Table 1).

\section{Template-Primer Specificity of RDDP Activity}

The RDDP activity in B cell-stimulated thymus cells utilized $(\mathrm{rA})_{\mathrm{n}} \cdot(\mathrm{dT})_{12-1.8}$ more efficiently than $(\mathrm{dA})_{\mathrm{n}} \cdot(\mathrm{dT})_{12-18}$ as the template-primer (Table 1 ). It also utilized $(\mathrm{rCm})_{\mathrm{n}} \cdot(\mathrm{dG})_{12}{ }_{18} \cdot{ }^{28}$ This template-primer specificity is quite similar to that of other mammalian reverse transcriptases..$^{29}$ As for fresh thymus cells and $B$ cells, the two peaks of RDDP activity that eluted at $0.06 \mathrm{M}$ and $0.35 \mathrm{M} \mathrm{KCl}$ transcribed $(\mathrm{rA})_{\mathrm{n}} \cdot(\mathrm{dT})_{12-1 \mathrm{~s}}$. However, almost the same or a higher level of DNA-directed DNA polymerase activity was observed, suggesting that these activities were due to contaminating cellular polymerases. The eluate at $0.15 \mathrm{M}$ $\mathrm{KCl}$ in the medium of mitomycin C-treated $\mathrm{B}$ cells (see above) transcribed $(\mathrm{dA})_{\mathrm{n}} \cdot(\mathrm{dT})_{12-18}$, but did not transcribed $(\mathrm{rCm})_{\mathrm{n}} \cdot(\mathrm{dG})_{12-18}$. Eluates at $0.06 \mathrm{M}$ $\mathrm{KCl}$ from both fresh and $\mathrm{B}$ cell-stimulated thymus cells transcribed $(\mathrm{rCm})_{n}$. $(d G)_{12-18}$ very poorly.

\section{DISCUSSION}

The presence of reverse transcriptase in normal human tissues has thus far been not conclusive. Positive results have been reported in placenta, sperm, milk, and the cultured fibroblasts.11,12,30-32 On the other hand, Green et al. could not detect the particle-associated reverse transcriptase activity in a variety of normal human cells, of both adult and embryonic origin. ${ }^{33}$ In our study reverse transcriptase activity could be demonstrated in the culture medium of $\mathrm{B}$ cell-stimulated fetal thymus cells. The enzyme activity differed from cellular polymerases in terms of template-primer requirement and ionic strength at which it was eluted from phosphocellulose. In an accompanying paper, $3 *$ we have detected retrovirus-like particles in fetal thymus cells by electron microscopy. RDDP activity sedimented in sucrose density gradients at the density characteristic of animal retrovirus. These RDDP activities detected here are therefore most probably reverse transcriptases.

Some authors have reported that $B$ cell lines are contaminated with retroviruses. ${ }^{3.5}$ Since reverse transcriptase activities and retrovirus-like particles were also present after stimulation with peripheral B cells, as well as B cell lines, ${ }^{34}$ retroviruses are unlikely to have been introduced by $\mathrm{B}$ cell lines. 
To our knowledge, this is the first demonstration of reverse transcriptase activities in freshly isolated human thymus cells by induction. Our results that reverse transcriptase activities were not present in fresh fetal thymus cells but only after induction suggest that RNA tumor protovirus activation in human fetal thymus cells. Further characterization of the reverse transcriptase activities is needed for detailed information concerning the significance of retrovirus in human thymus.

\section{ACKNOWLEDGEMENT}

We would like to express our sincere appreciation to Professors W. K. Joklik and D. B. Amos of Duke University for valuable discussions. We also thank Dr. K. Iwakura for providing thymus tissues and Dr. T. Goto, Osaka Medical College, for providing MuLV producer cell lines. The excellent technical assistance of Mrs. Kikuchi and Mrs. Nakamura is acknowledged.

\section{REFERENCES}

1. Rous, P.: A sarcoma of the fowl transmissible by an agent separate from the tumor cells. J. Exp. Med. 13: 397-411, 1911

2. Gross, L.: "Spontaneous" leukemia developing in $\mathrm{C} 3 \mathrm{H}$ mice following inoculation in infancy, with A-K leukemic extracts, or A-K embryos. Proc. Soc. Exp. Biol. Med. 76: 27-32, 1951

3. Teich, N.: Taxonomy of retrovirus. In: R. Weiss, N. Teich, H. Vernas and J. Coffin (ed.), RNA Tumor Viruses. pp. 25-208, Cold Spring Harbor Laboratory, 1982

4. Temin, H. M.: The cellular and molecular biology of RNA tumor viruses especially avian leukosis-sarcoma and their relatives. Adv. Cancer Res. 19: 47-104, 1974

5. Aaranson, S., Todaro, G. and Scolnik, E.: Induction of murine C-type viruses from clonal lines of virus-free Balb/3T3 cells. Science 174: 157-159, 1971

6. Wong-Staal, F., Gallo, R.C. and Gillespie, D.: Genetic relationship of a primate RNA tumor virus genome to genes in normal mice. Nature 256: 670-672, 1975

7. Nooter, K., Aarssen, A. M., Bentvelzen, P., F. G. de Groot and F. G. Pelt.: Isolation of Infectious C-type oncornavirus from human leukemic bone marrow cells. Nature 256: 589-591, 1975

8. Balba, B. R., Helmann, R., Cho, J.-R. and Spiegelman, S. A.: Oncornavirus-like particles in human skin cancers. Proc. Natl. Acad. Sci. U.S.A. 72: 3697-3700, 1975

9. Teich, N. M., Weiss, R. A., Salahuddin, S.Z., Gallangher, R. R., Gillespie, D. H. and Gallo, R.C.: Infective transmission and characterization of a C-type virus released by cultured human myeloid leukemia cells. Nature 256: 551-555, 1975

10. Kaplan, H. S., Goodnew, R. S., Epstein, A. C., Cartner, S., Decleve, A. and Rosenthal, P. N.: Isolation of a type C RNA virus from an established human histiocytic lymphoma cell line. Proc. Natl. Acad. Sci. U.S.A. 74: 2564-2568, 1977

11. Imamura, M., Phillips, P. E. and Mellors, R. C.: The occurence and frequency of type $C$ virus-like particles in placentas from patients with systemic lupus erythematosus and from normal subjects. Am. J. Pathol. 83: 383-394, 1976

12. Dirksen, E. R. and Levy, J. A.: Virus-like particles in placentas from normal individuals and patients with systemic lupus erythematosus. J. Natl. Cancer Inst. 59: $1187-1192,1977$

13. Kacian, H.S.: On the natural history of the murine leukemias. Presidental Address. Cancer Res. 27: 1325-1340, 1967 
14. Old, L. J., Boyse, E. A. and Stockert, E.: Antigenic properties of experimental leukemias. I. Serological studies in vitro with spontaneous and radiation-induced leukemias. J. Nat. Cancer. Inst. 31: 977-986, 1963

15. Poiesz, B.J., Ruscetti, F. W., Gazdar, A. F., Bunn, P. A., Minna, J. D. and Gallo, R. C. Detection and isolation of type $C$ retrovirus particles from fresh and cultured lymphocytes of a patient with cutaneous T-cell lymphoma. Proc. Natl. Acad. Sci. U.S.A. $77: 7415-7419,1980$

16. Hinuma, Y., Nagata, K., Hanaoka, M. et al.: Adult T-cell leukemia: Antigen in an ATL cell line and ditection antibodies to the antigen in human sera. Proc. Natl. Acad. Sci. U.S.A. 78: 6476-6480, 1981

17. Miller, J. F. A. P.: Immunological function of the thymus. Lancet ii: 748-749, 1961

18. Ono, A., Amos, D. B. and Koren, H. S.: Selective cellular natural killing against human leukemic $\mathrm{T}$ cells and thymus. Nature 266:546-548, 1977

19. Ono, A.: Cellular natural killing against thymocytes. Keio J. Med. 27: 23-36, 1978

20. Adams, R. A.: Formal discussion: The role of transplantation in the experimental investigation of human leukemia and lymphoma. Cancer Res. 27: 2479-2482, 1976

21. Epstein, M. A., Achong, B. G., Barr, Y. M.: Virus particles in cultured lymphoblasts from Burkitt's lymphoma. Lancet i: 702-703, 1964

22. Imagawa, D. T., Issa, H. and Nakai, M.: Cultivation of Gross virus-induced murine thymic lymphoma cells in vitro. Cancer Res. 28: 2017-2026, 1968

23. Kacian, D. L.: Methods for asseying reverse transcriptase. In: Methods in Virology. Vol. IV. pp. 143-183. New York: Academic Press, 1977.

24. Sarin, P.S., Danlon, J., Friedman, B. and Gallo, R. C.: Characterization of an RNA-directed DNA polymerase from a cell line derived from a radiation-induced lymphoma in mice. Biochi. Biophy. Acta 564: 234-245, 1979

25. Hillova, J., Hill, M. and Kalekine, M.: Inability of the nondefective Rous sarcoma provirus to generate, upon transfection, a transformation defective virus. Virology $74: 540-543,1976$

26. Sarin, P. S., Friedman, B. and Gallo, R. C.: Purification and charactrization of baboon endogenous virus DNA polymerase. Biochi. Biophy. Acta 479: 198-206, 1977

27. Goodman, S. R., Prezyna, C. and Benz, W. C.: Two Epstein-Barr virus associated DNA polymerase activities. J. Biol. Chem. 253: 8617-8628, 1978

28. Gerard, G. F., Lowenstein, P. M. and Green, M.: Charactrization of a DNA polymarase activity in cultured human melanoma cells that copies poly (2'-omethylcytidylate). J. Biol. Chem. 255: 1015-1022, 1980

29. Sarngadharan, M. G., Allandeen, H. S. and Gallo, R. C.: Reverse transcriptase of RNA tumor viruses and animals. Meth. Cancer Res. 12: 3-47, 1976

30. Kalter, S. S., Helmke, R. J., Heberling, R. L. et al.: C-type particles in normal human placentas. J. Natl. Cancer Inst. 50: 1081-1094, 1973

31. Schlom, J. and Spiegelman, S.: Detection of high-molecular-weight RNA in particles from human milk. Science 175: 542-544, 1972

32. Panem, S., Prochownik, E. V., Reale, R. and Kirsten, W. H.: Isolation of C type virus from a normal human fibroblast strain. Science 189: 297-299, 1975

33. Gerard, G. F. and Green, M.: Do normal human cells express RNA tumor virusrelated information? In: Ito (ed.), Prog. Exp. Tumor Res. Vol. 22, pp. 250-269. Berlin: Karger, 1978

34. Ono, A., Higashinakagawa, T., Nakamura, T. et al.: RNA tumor virus-like particles in human fetal thymus cells stimulated by human B cells. Gann 74: 802-805, 1983

35. Kotler, M., Balabanoba, H., Weinberg, E., Fridmann, A. and Becker, Y.: Oncornavirus-like particles released from arginine-deprived human lymphoblastoid cell lines. Natl. Acad. Sci. U.S.A. 72: 4592-4596, 1975 